\title{
Decision Development of Constitutional Court on Heritage Rights of Children Outside of Marriage
}

\author{
Devi Sumiwardani ${ }^{*}$ \\ *) Public Notary in Pati Regency
}

\begin{abstract}
Based on Islamic law and the Civil Code, children who born outside of marriage have a different status with legitimate children. This difference is due to the validity of the marriage relationship. It seems that the issue of children outside of marriage in Indonesia is still being questioned by people, even though conceptually or in formal juridical terms there are legal provisions regulating it. In society and the law, confusion often occurs due to differences in legal rules. The issues that will be discussed in this research are; (1) How is the implementation of the inheritance rights of children outside of marriage according to positive law in Indonesia? (2) How are legal protection measures for children outside of marriage? and (3) What is the legal consequence of the Constitutional Court Decision which is seen as a development towards the inheritance rights of children outside of marriage? This research uses a normative juridical approach that analyzes articles in statutory regulations. The research specification is descriptive analytical, which aims to provide a detailed, systematic and comprehensive description of the civil rights issues of children outside of marriage. The data collection method uses primary legal materials consisting of books and opinions of scholars and various laws and regulations and secondary legal materials consisting of internet sites. The conclusion of this study is that children outside of marriage have legal consequences, namely the consequences of having the right to legal recognition and protection if they fulfill Article 2 paragraph (2) of Act No. 1 of 1974. The Constitutional Court's decision is of the opinion of Article 43 paragraph (1) of Act No. 1 of 1974 that "children who born outside of marriage only have a civil relationship with their mother and their mother's family, as well as men as their father, which can be proven based on science and / or other evidence by law to have blood relations including civil relations with their father's family. The Constitutional Court decision only concerns children resulting from marriage who are not registered, not children resulting from adultery. Regarding the result of adultery children who do not have a family relationship, marriage guardian, inheritance and income from the male who caused the birth.
\end{abstract}

Keywords: Constitutional; Heritage; Children; Outside of Marriage.

\section{Introduction}

The law of marriage is an integral part of Islamic law, which is inseparable from the dimensions of Islamic faith and morals. On this basis, the law of marriage wants to realize marriage among Muslims into a marriage that is monotheistic and moral, 
because this kind of marriage can be expected to have transcendental and sacred values to achieve the goal of marriage that is in line with the goals of Islamic law. ${ }^{1}$

The provisions regarding marriage according to Islamic law are binding on every Muslim, and every Muslim needs to be aware that marriage contains Ubudiyah values. Therefore, the marriage bond is termed by the Qur'an as "Mitsaaqan Ghalidza", a strong promise. As a bond that contains Ubudiyah values, paying attention to its validity is a very principle thing. ${ }^{2}$

The validity of a marriage is a very principle matter, because it is closely related to the consequences of marriage, both those related to children (descendants) and those related to property. Act No. 1 of 1974 concerning Marriage (UUP) has formulated the criteria for the validity of a marriage, which are regulated in Article 2, as follows:

(1) Marriage is legal if it is carried out according to the law of each religion and belief.

(2) Each marriage is recorded according to the applicable laws and regulations.

So far, the issue of marriage in Indonesia is regulated in Act No. 1 of 1974 concerning Marriage. The existence of the Marriage Law in Indonesia is intended to accommodate the diversity of marriage regulations and provide a legal basis for marriage that can be used as guidance and applies to all groups of society in Indonesia.

Children who are born carry children's rights which in principle should not be treated differently or discriminated against. However, children from a marital relationship are registered, or not registered, or children who born not in a legal marriage relationship, but the child remains authentic as a legal subject who has equal child rights.

The condition of the marital relationship or the juridical obstacles in the marriage of the parents, the impact is not passed on to the child. In addition, children have the right to the responsibilities of their parents, even though the consequences of marriage are not recorded, even non-marital children. The relationship between a child and a man as the father is not solely due to the marriage bond. This is in accordance with the Decision of the Constitutional Court Number 46 / PUU-VIII / 2010. According to the Constitutional Court, it is neither right nor fair if the law stipulates that a child born from a pregnancy due to sexual relations outside of marriage only has a relationship with the woman as the mother.

The main issue of the law regarding children who born outside of marriage is the legal meaning of the phrase "born outside of marriage". To obtain answers from a broader perspective, it is necessary to answer related problems, namely the problem of the legitimacy of children. ${ }^{3}$

A marriage bond is said to be valid if it is carried out according to applicable law. If a marriage is not carried out according to law, it can be said that the marriage is not

\footnotetext{
${ }^{1}$ Drs. HM Anshary MK, SH, MH. (2010). Hukum Perkawinan di Indonesia. Yogyakarta: Pustaka Pelajar. p. 10

2 Ibid., p. 11

3 Chatib, Rasyid. et al. (2012). Akibat Hukum Terhadap Anak Diluar Perkawinan Pasca Putusan Mahkamah Konstitusi. Yogyakarta: Total Media. p. 30
} 
legally valid. The consequence of such an illegitimate marriage is that it is not protected by applicable law, both the husband and wife who are related to the marriage and the children who born from the marriage. ${ }^{4}$ So that the child born from this marriage is not entitled to demand a living, education costs or inheritance from his father.

In the Marriage Law in Indonesia, Article 43 paragraph (1) states that children who born outside of marriage only have a civil relationship with the mother and the mother's family. This will be seen in the birth certificates of children who born from such illegitimate marriages or children who born outside of marriage. What is recorded is the name of the child, the day and date of birth, the order of birth, the name of the mother. ${ }^{5}$ So the point is that the child's birth certificate will only mention the mother's name without mentioning the father's name.

In Islamic law, children outside marriage are identified with children who born as a result of adultery. The concept of Zina in Islamic law is very different from the terminology of adultery in the Civil Code. The Civil Code only maintains the principle of monogamy, where at the same time a man can only be married to a woman and on the other hand, a woman can only be married to a man. ${ }^{6}$ Whereas in the conception of Islamic Law, adultery is where all acts of intercourse between a man and a woman without a marriage bond. ${ }^{7}$ Based on the description above, the following problems can be formulated: How is the implementation of the inheritance rights of children outside of marriage according to positive law in Indonesia; How are legal protection measures for children outside of marriage; and What is the legal consequence of the Constitutional Court decision which is seen as a development towards the inheritance rights of children outside of marriage.

\section{Research Methods}

This research uses a normative juridical approach that analyzes articles in statutory regulations. The research specification is descriptive analytical, which aims to provide a detailed, systematic and comprehensive description of the civil rights issues of children outside of marriage. The data collection method uses primary legal materials consisting of books and opinions of scholars and various laws and regulations and secondary legal materials consisting of internet sites.

\section{Result and Discussion}

\subsection{Implementation of Inheritance Rights of Children Outside Marriage According to Positive Law in Indonesia}

\subsubsection{Islamic Law Perspective of Jurisprudence}

\footnotetext{
${ }^{4}$ Government Regulation Number 37 of 2007 concerning the implementation of Act No. 23 of 2006 concerning Population Administration, article 55 paragraph (2) letter a

${ }^{5}$ lbid.

${ }^{6}$ DY Witanto. (2012). Hukum Keluarga Hak dan Kedudukan Anak Luar Kawin Pasca Putusan MK Tentang Uji Materiil UU Perkawinan. Prestasi Pustakaraya. p. 59

${ }^{7}$ Ibid., p. 60
} 
When analyzed the Figh view regarding this legal child, it can be understood that the legal child begins from the conception or fertilization of the egg (ovum) by sperm which occurs in the womb of the woman who is the prospective mother and this conception must occur in a legal marriage. This is where the determination of the legal child is carried out. Thus Islamic Law states that in order for a child to be considered as the legitimate child of the mother's husband, the child must be born at least six months after marriage or within 'Iddah' for four months and ten days after the marriage is terminated.

Regarding this grace period, there is a flow among jurisprudents who argue that a child born after exceeding the 'Iddah grace period after the marriage is terminated, is a legitimate child of a former husband as long as it can be considered that the birth was caused by the act of intercourse between the former husband and wife. Given this difference in opinion, a maximum grace period of four years is established, provided that it is clear that in the past four years the mother has not excreted any feces. Thus, if the baby is born less than six months, from the time of marriage, the child cannot be related to his / her father's kinship, even though he was born in a legal marriage. He only has a family relationship with his mother.

This is where the difference between the Fiqh view and the Marriage Law in Indonesia, because the Fiqh view does not recognize the registration of marriage, the meaning of marriage outside of marriage is the same as Zina, while the Marriage Law in Indonesia, because it requires registration, cannot be equated between outside marriage and adultery. Outside of marriage in Indonesia according to Figh is legal, while adultery according to Fiqh's view is that it has never been touched by the term marriage.

\subsubsection{Itsbat Marriage for Children's Purposes}

In Indonesia, there are many children who born outside of marriage, namely marriages carried out according to religious law, guidelines for legalization of marriage, contained in Article 7 of the Compilation of Islamic Law (KHI) as follows:

a. Marriage can only be proven with a marriage certificate prepared by the Marriage Registration Officer.

b. In the event that a marriage cannot be proven by a marriage certificate, it can be filed Itsbat get married to the Religious Court.

c. Itsbat marriage that can be submitted to the Religious Court is limited to matters relating to:

1) There is a marriage in the framework of divorce settlement;

2) Loss of marriage certificate;

3) There are doubts about whether or not one of the conditions of marriage is valid;

4) The existence of marriages that occurred before the enactment of Act No. 1 of 1974, and;

5) Marriage that is carried out by those who do not have a marriage barrier according to Act No. 1 of 1974.

In accommodating the decision of the Constitutional Court Number 46 / PUU-VIII/2010 in addition to the matters mentioned in Article 7 paragraph (3) above, the marriage 
certificate which can be submitted to the Religious Court is added with one more point, with "for the purposes of child validation". This applies to legalization of marriage for all cases of unauthorized marriages or disputed marriages, whether for non-polygamous marriages or for polygamous marriages. Especially for the ratification of polygamy, it must be guided by:

a. Act No. 1 of 1974 Concerning Marriage ${ }^{8}$ In Article 3 (2), Article 4 (1), Article 4 (2), Article 5 (1), and Article 5 (2).

b. Government Regulation Number 9 of 1975 concerning Implementation of Act No. 1 of 1974 concerning Marriage ${ }^{9}$ Article 40 and Article 41.

The provisions mentioned above are of course applied to the requirements for polygamy permits and conditions that are still possible, but if it is no longer possible, such as the case of Machica with Moerdiono (who has passed away), then legal considerations are wisely left to the judgment and views and opinions of the judge to grant it. or not, in line with Article 43 of Government Regulation Number 9 of 1975 concerning the Implementation of Act No. 1 of 1974 concerning Marriage which states: if the court is of the opinion that there is sufficient reason for the applicant to have more than one wife, the court will issue a decision in the form of permission to have more than one wife.

However, the product of the court in this case is no longer a permit for polygamy, but a legalization of marriage with polygamous status for the purpose of completing the requirements for child validation. Examination of the requirements governing polygamy permits is only needed as support for legalization of a polygamous marriage, not for the stipulation of a polygamy license.

It could even be that an examination of the legalization (Itsbat of marriage) with the status of polygamy, there is no need for a separate stipulation, it is enough to combine it with the ruling on child legalization. It is the judge's authority.

\subsubsection{Constitutional Court Decision}

The Constitutional Court Decision Number 46 / PUU-VIII / 2010 dated 17 February 2012 decided that Act No. 1 of 1974 Article 43 concerning Marriage is contrary to the 1945 Constitution if it is not read: "Children who born outside of marriage have a civil relationship with their mother and their mother's family as well as with men. -Male as a father who can be proven based on science and technology and / or other evidence according to the law has a blood relationship including a civil relationship with his father's family "replacing the previous article" a child born outside of marriage only has a civil relationship with his mother and his mother's family".

The objective of the Constitutional Court emphasizes the importance of protection and legal certainty that is fair to the status of children who born and the rights that exist to

\footnotetext{
${ }^{8}$ Act No. 1 of 1974 Concerning Marriage, In the Book of the Compilation of Regulations on Religious Courts, p. 403

9 Government Regulation Number 9 of 1975 Concerning Implementation of Act No. 1 of 1974 Concerning Marriage in the Book of the Compilation of Regulations on Religious Courts 2010. p. 422
} 
it, including the rights of children who are born even though its legality is still in dispute.

\subsubsection{DNA as Proof}

Children who born outside of marriage can breathe a sigh of relief, because the Constitutional Court granted some of the petition for review, namely according to the Constitutional Court Article 43 paragraph (1) which regulates the civil relationship of children outside of marriage is contrary to the 1945 Constitution.

Article 43 paragraph (1) which initially reads "Children who born outside of marriage only have a civil relationship with their mother and their mother's family", but the above paragraph should be read "Children who born outside of marriage have a civil relationship with their mother and mother's family as well as with boys. as his father who can be proven based on science and technology and / or other evidence according to the law has a blood relationship, including a civil relationship with his father's family".

DNA testing is a way of proving the status of the child outside of marriage to the biological father. The sophistication and accuracy of DNA test results cannot be doubted or refuted, so that the results of this technology in the biomolecular field have become a "helper god" for children whose status is unclear who the real father is.

\subsection{Legal Protection Efforts for Children Outside Marriage}

\subsubsection{Children who born outside of marriage}

Basically marriage in Indonesia must be carried out according to the procedure in accordance with Article 2 Paragraph 1 and 2 of Act No. 1 of 1974 concerning Marriage, that is what is meant by real marriage according to Act No. 1 of 1974. If the marriage is carried out only by following Article 2 Paragraph 1 only, then the marriage is called "outside marriage", therefore Article 43 Paragraph 1 of Act No. 1 of 1974 concerning marriage does not stand alone, it is closely related to the existence of marriage.

It is called "outside of marriage" because the marriage is carried out outside the procedure in Article 2 Paragraph 2. It is very unlikely that "outside of marriage" can be interpreted as adultery, because the act of adultery is done completely without marriage, there is a huge difference between "outside of marriage" and without marriage. The analogy is compared with the words: I sleep outside the house, which means the house is there but I sleep outside, at one point I can sleep going into the house, but if I sleep without a house, it means that the house is not there, until whenever I can not enter the house. Therefore, if it is called "outside of marriage" it is certain that the marriage has been carried out at least in accordance with Article 2 Paragraph 1 of Act No. 1 of 1974 concerning Marriage, that is what is called "outside of marriage", while adultery is completely untouched by the term "marriage".

\subsubsection{Constitutional Court Decision}

The Constitutional Court Decision Number 46 / PUU-VIII / 2010 has never touched a child born without marriage or a child resulting from adultery. The focus considered by the Constitutional Court Decision is children outside of marriage related to the absence 
of marriage registration and marriage disputes. The legal considerations of the Constitutional Court in the "Court Opinion" are as follows:

a. Consideration number (3.12) reads:

Considering whereas the main issue of the law is regarding the registration of marriage according to regulations regulation is about the legal meaning of marriage registration. Regarding this matter, the General Elucidation of number 4 letter b of Law 1/1974 concerning the Principles or Principles of Marriage states, "... that a marriage is valid if it is carried out according to the law of each of his religions and beliefs; and besides that, every marriage must be recorded according to the applicable regulations. The registration of every marriage is the same as the recording of important events in a person's life, for example, a birth, death which is stated in certificates, an certificate which is also included in the register of registration."

Based on the explanation of Act No. 1 of 1974 above, it is only that (i) marriage registration is not a factor determining the validity of a marriage and (ii) registration is an administrative obligation that is required under the UU regulations.

The factors that determine the validity of a marriage are the conditions determined by the religion of each prospective bride and groom. The mandatory registration of marriages by the state through legal regulations is an administrative obligation.

b. The numerical considerations (3-13) read:

Considering whereas the main issue of the law regarding children who born outside of marriage is the legal meaning (legal meaning) of the phrase "born outside of marriage". To obtain answers from a broader perspective, it is necessary to answer related problems, namely the problem of the legitimacy of children.

Naturally, it is impossible for a woman to become pregnant without the encounter between ovum and spermatozoa either through sexual intercourse (coitus) or through other means based on technological developments that lead to fertilization. Therefore, it is inappropriate and unfair when the law stipulates that a child born from a pregnancy due to sexual relations outside of marriage only has a relationship with the woman as the mother.

Thus, regardless of the procedure/administration of marriage, children who born must receive legal protection. If this is not the case, then the one who is harmed is the child who was born outside of marriage, even though the child is innocent because the child was born out of his will. Children who are born without the clear status of the father often get unfair treatment and stigma in society. The law must provide protection and just legal certainty for the status of a child who is born and the rights that exist to it, including for children who are born even though the legality of the marriage is still disputed.

The explanations in the two legal considerations of the Constitutional Court all relate to the registration of marriages and marriages in dispute. It has absolutely nothing to do with the child of adultery. Adultery does not recognize recording and adultery there is no marital dispute because adultery does not recognize marriage, if there is no 
marriage where a marriage dispute arises. The understanding that the Constitutional Court Decision Number 46 / PUU-VIII / 2010 relates to children resulting from adultery is a misunderstanding of opinion.

If the Constitutional Court's consideration number (3.13) is understood as adultery, it is very confusing because all sexual relations that result in pregnancy due to the meeting between the ovum and spermatozoa are not just adultery, even a legal marriage relationship will occur.

\subsubsection{Legal Protection for Children}

Act No. 23 of 2002 concerning Child Protection has regulated aspects of child protection which support each other. The implementation of child protection includes aspects of religion, health, education and special protection. Meanwhile, children's civil rights are part of the effort to fulfill children's rights. Children's civil rights are regulated in the Child Protection Law, Section Chapter Child Status. The provisions specifically regulated in Article 27 are as follows:

a. Each child's identity must be given from birth;

b. The identity as meant in paragraph (i) is written in the birth certificate;

c. Making a birth certificate is based on a certificate from the person who witnessed and or helped the birth process;

d. In the case of a child whose birth process is unknown and whose parents are unknown, the creation of a birth certificate for the child is based on the information of the person who found it.

Other related provisions are provisions regarding children's rights to know their parents as regulated in Article 7 of the Child Protection Law:

a. Every child has the right to know his parents, to be raised and cared for by his own parents;

b. In the event that for some reason the parents cannot guarantee the growth and development of the child or the child is neglected, the child has the right to be cared for or adopted as a foster child or adopted child by another person in accordance with the provisions of the applicable laws.

According to Muhammad Juni, the best interests of children must be seen as paramount importance or top priority; The principle of life circle approach, an understanding must be formed that protection of children must start early and be sustainable, that the fate of children is very dependent on various macro and micro factors, both directly and indirectly. ${ }^{10}$

Rights are tools that allow citizens of society to freely develop their talents to fulfill their duties properly. ${ }^{11}$ This possibility must be held by the state by establishing legal norms or regulations. The rules of law that provide members of society to develop

10 Joni, Muhammad. (1999). Aspek Hukum Perlindungan Anak Dalam Perspektif Konvensi Hak Anak, Bandung: Citra Aditya Bakti. p. 106

${ }^{11}$ Ferdiyanti, M. Indah Verena., Purnawan, Amin., \& Soegiyanto. (2019). Setting the Effectiveness of Law Position and Code Notary to the Quality of Performance. JURNAL AKTA: Vol. 6, No. 4, 797-804. Retrieved from http://jurnal.unissula.ac.id/index.php/akta/article/view/7887 
their talents are more beneficial for the development of law and for the achievement of legal order.

According to Maulana Hassan Waddong, child protection can be divided into; juridical protection, including protection in the field of civil law and in criminal law and protection of a non-juridical nature, including protection in the social, health and education fields. ${ }^{12}$

According to Arief Gosita, child protection efforts can be divided into direct and indirect protection, and juridical and non-juridical protection. Direct protection measures include: provision of things so that children are protected and saved from something that endangers them, prevention from anything that can harm or sacrifice children, supervision, guarding against disturbances from within or outside of themselves, mentoring (mental, physical, social), correctional formal and informal education, care, reward, arrangements in the regulations of the Republic. ${ }^{13}$

Child protection is needed so that a child can get his rights and obligations. The definition of child protection according to Act No. 4 of 1979 concerning Child Welfare is: ${ }^{14}$

a. All efforts are made consciously by every person and government, private institution with the aim of safeguarding, controlling and fulfilling the physical, mental and social welfare of children and adolescents in accordance with their human rights interests.

b. All collective efforts made consciously by individuals, families, communities, government and private agencies for the security, provision and fulfillment of the spiritual and physical welfare of children aged 0-21 years, not and have never been married in accordance with their human rights and interests so that can develop himself as optimally as possible.

This principle of child welfare should be seen as the main focus of the juvenile justice system. This principle can be used as a basis for not applying sanctions that are purely criminal or punitive in nature. ${ }^{15}$ Protection can also be defined as all efforts aimed at preventing, rehabilitating and empowering children who have experienced child abuse, exploitation and neglect, in order to ensure the child's survival and development in a reasonable manner, physically, mentally and socially. ${ }^{16}$ Legal protection in the civil sector is accommodated in the provisions of civil law regulating children, such as: 1 ) the position of the legal child in inheritance law, 2) recognition and legalization of

\footnotetext{
12 Waddong, Maulana Hassan. (2000). Pengantar Advokasi Dan Hukum Perlindungan Anak. Jakarta: PT Gramedia Indonesia. p. 40

13 Gosita, Arief. (1996). Paper of Pengembangan Aspek Hukum UU Peradilan Anak Dan Tanggung Jawab Bersama, National Seminar on Child Protection, UNPAD. Bandung. p. 6

${ }^{14}$ Krinawati, Emiliana. (2005). Aspek Hukum Perlindungan anak. Bandung. p. 3

${ }^{15}$ Muladi. (1992). Bunga Rampai Hukum Pidana. Bandung: Alumni Publisher. p. 113

${ }^{16}$ Gosita, Arif. Masalah Perlindungan Anak. Jakarta: Akademi Presindo. p. 52
} 
children outside of marriage, 3) obligations of parents to children, 4) immaturity of children and guardianship. ${ }^{17}$

Child protection is beneficial for children and their parents as well as the government, so coordination of child protection cooperation needs to be held in order to prevent imbalance in child protection activities as a whole. According to Barda Nawawi Arief, this is an effort to protect the law on various freedoms and human rights of children (fundamental rights and freedoms of children) as well as various interests related to the welfare of children.

Meanwhile, the concept of parents is not only a pure civil concept but has implications for religious issues. In this context, children have rights and therefore we must provide protection in carrying out religious teachings, including humanitarian affairs and the like. This is explicitly regulated in Article 42 paragraph (1) of the Child Protection Law; "Every child has protection to worship according to their religion. Provisions regarding lineage, guardians and heirs are part of religious norms whose rights must be fulfilled. ${ }^{18}$

The Constitutional Court, as part of a state institution like other state institutions, has the responsibility to ensure the protection of children in embracing religion, as stipulated in Article 43 paragraph (1) of the Child Protection Law which emphasizes "The state, government, society, family, parents, guardians and social institutions ensure the protection of children in embracing their religion ". The determination of the lineage of the child outside of marriage to the mother is intended to protect the child's family and other related religious provisions, not as a form of discrimination.

With these explanations, it is clear that children outside of marriage are the same as other Indonesian children who receive protection from the Child Protection Law and are legally protected by making birth certificates and other protections. Thus the opinion that states that children outside of marriage are neglected and unprotected, even if seen from neglected and unprotected children on the streets, in slum areas most of them are legitimate children.

\subsection{Development of Constitutional Court Decisions on Inheritance Rights of Children Outside Marriage}

Children are the result of a marriage and children are one of the important goals of a marriage. A child is the next generation for his parents or family. Children will give happiness in the middle of the family and can help their parents when the child grows up. If one of the parents has died, for example the father dies, the mother can live among the children and grandchildren and a child will definitely take care of his parents when he is sick. In QS. An-Nahl verse 72 which means: "Allah made for you wives of your own kind and made your children and grandchildren from your wives."

\footnotetext{
17 Retnowulan. (1996). Hukum Acara Peradilan Anak. National Seminar on Child Protection, Faculty of Law UNPAD. Bandung. p. 3

18 Yensih, \& Sukarmi, Hanim, Lathifah. (2019). The Law Strength Of Under Hand Deed That Has Passed By Notary as an Authentic Deed in the Proof of Civil Case in District Court of Cirebon. JURNAL AKTA: Vol. 6, No. 4, 661-668. Retrieved from http://jurnal.unissula.ac.id/index.php/akta/article/view/7596
} 
Even though these children are the children of father and mother, in this glorious verse, a very close bond between parents and children is described, and the responsibility of parents towards their children is added. ${ }^{19}$

Every child has rights and obligations. The right of every child to be protected and cared for by their parents. In Islam, children are seen as entertainment, jewelry, as well as a way to continue one's descent. Islam instructs every human being to have children but at the same time also affirms that these children must be good and pious which requires intensive efforts to raise them properly. The ability to properly raise children is an inherent guide to marriage in Islam.

Son means the second descendant. A child is the next generation of its parents, with the birth of a husband and wife child will become parents as well as the father and mother of the child's parents will become a grandfather and grandmother. It can be said that parents are the first descendants of grandparents, while children are the second descendants of grandparents.

On February 17, 2012 the Constitutional Court decided on a request for a judicial review of Article 43 paragraph (1) of Act No. 1 of 1974 which was submitted by Aisyah Muhtar. Article 43 (1) states that children who born out of wedlock only have a civil relationship with their mother and their mother's family. According to the Constitutional Court, this article is contrary to the 1945 Constitution, then the Constitutional Court decides that a biological child has a civil relationship with his biological father as long as it can be proven based on science and technology and / or other evidence according to law.

After the decision, the Constitutional Court argued that Article 43 paragraph (1) of Act No. 1 of 1974 should be read: "Children who born outside of marriage only have a civil relationship with their mother and their mother's family, as well as with men as children that can be proven based on science and or other evidence according to the law has a blood relationship, including a civil relationship with his father's family ". The legal consequence of birth due to pregnancy through sexual intercourse is the existence of a legal relationship in which there are reciprocal rights and obligations whose legal subjects include the child, mother and father. So far, children who are born without clear father status often receive unfair treatment and negative stigma in society.

The implications of the Constitutional Court decision are very large, regarding social, moral and legal aspects. The institution of marriage can be seen as increasingly important or vice versa is seen as no longer important, considering that children outside of marriage can obtain rights from their biological father, as in general juridical children or children who born from legal marriages. The father-son relationship, thus, is not based solely on the existence of a marriage contract (marriage bond), but can also be based on proving the existence of a blood relationship through science and technology.

\footnotetext{
${ }^{19}$ Shalaby, Ahmad. (2001). Kehidupan Sosial dalam Pemikiran Islam. Jakarta: Amzah. p. 52
} 
The Constitutional Court Decision Number 46 / PUU-VII / 2010 received mixed reactions. Among those who refused was MUI who considered the Constitutional Court's decision to damage the Islamic legal order considering that the act of adultery is a criminal act, even MUI argues that in terms of procedural law, the Constitutional Court's decision exceeds the Petitioner's demands (Ultra Petita), the more so MUI sees The Constitutional Court did not explain further about the "civil relations" meant in the decision, even though this is the point of the controversy.

The Constitutional Court's decision emphasized that biological children have a civil relationship with biological fathers and their biological father's family, naturally experiencing confusion both pros and cons. Long before that Prof. Bustanul Arifin has complained that if an out of wedlock child is not needed to be balanced (with a legitimate child) before the father (biological), it can mess up the noble institution of marriage. However, in accordance with the Elucidation of Article 10 of Act No: 24 of 2003 concerning the Constitutional Court which has been amended by Act No: 8 of 2011, the Constitutional Court decisions are final and binding. This means that there is no legal remedy available to review the Constitutional Court decision, except through amendments to the Law on the Court itself.

Furthermore, MUI offers a solution for Ulil Amri to implement Ta'zir for the biological father of the father of an out-of-wedlock child by obliging him to meet the needs of the child, as well as providing a share of the assets after the biological father dies through Wasiat Wajibah. This is so that the civil rights of children are fulfilled without violating Islamic law. Guarding the rights of innocent children must be considered by parents regardless of whether the child is legal or illegitimate. It seems that the solution offered by MUI may only be contained in a Government Regulation as promised by Article 43 paragraph 2 of Act No. 1 of 1974 which does not yet exist.

The positive law of our country and Islamic law do not recognize any inherited sins, in this case the child does not share the sanctions for mistakes made by their parents. However, marriages that are not carried out in accordance with Act No. 1 of 1974 carry risks for those who do so because the state cannot provide protection regarding marital status, property, inheritance and other rights arising from marriage, because to prove the existence of rights the rights of husband, wife and children must first be proven by the existence of a legal marriage between the husband and wife.

\section{Closing}

The implementation of the inheritance rights of children outside of marriage according to positive law in Indonesia is that marriages that are not religiously recorded are legal if they meet the conditions and harmonious conditions of marriage. Marriages not recorded in the positive law are invalid because they are not recognized by the state. However, the inheritance rights of children can still be exercised. In the Constitutional Court Decision Number 46 / PUU-VIII / 2010 for the purpose of child legalization, marriage is carried out. Meanwhile, the amount or amount of part that the child will get outside of marriage is still subject to the provisions of the Islamic inheritance law. And the legal protection measures for children from unregistered marriages are efforts aimed at preventing, rehabilitating and empowering children who have experienced 
acts of mistreatment, exploitation and neglect, in order to ensure the survival and development of children naturally, physically, mentally and socially.

To the Government and all people should concern on term of Child protection which benefi for children and their parents as well as the government, so coordination of child protection cooperation needs to be held in order to prevent imbalance in child protection activities as a whole according to Act No. 4 of 1974 concerning Child Welfare.

\section{References}

Journals:

[1] Ferdiyanti, M. Indah Verena., Purnawan, Amin., \& Soegiyanto. (2019). Setting the Effectiveness of Law Position and Code Notary to the Quality of Performance. JURNAL AKTA: Vol. 6, No. 4, 797-804. Retrieved from http://jurnal.unissula.ac.id/index.php/akta/article/view/7887

[2] Yensih, \& Sukarmi, Hanim, Lathifah. (2019). The Law Strength Of Under Hand Deed That Has Passed By Notary as an Authentic Deed in the Proof of Civil Case in District Court of Cirebon. JURNAL AKTA: Vol. 6, No. 4, 661-668. Retrieved from http://jurnal.unissula.ac.id/index.php/akta/article/view/7596

Books:

[1] Chatib, Rasyid. et al. (2012). Akibat Hukum Terhadap Anak Diluar Perkawinan Pasca Putusan Mahkamah Konstitusi. Yogyakarta: Total Media

[2] Drs. HM Anshary MK, SH, MH. (2010). Hukum Perkawinan di Indonesia. Yogyakarta: Pustaka Pelajar

[3] DY Witanto. (2012). Hukum Keluarga Hak dan Kedudukan Anak Luar Kawin Pasca Putusan MK Tentang Uji Materiil UU Perkawinan. Prestasi Pustakaraya

[4] Gosita, Arief. (1996). Paper of Pengembangan Aspek Hukum UU Peradilan Anak Dan Tanggung Jawab Bersama, National Seminar on Child Protection, UNPAD. Bandung

[5] Gosita, Arif. Masalah Perlindungan Anak. Jakarta: Akademi Presindo

[6] Joni, Muhammad. (1999). Aspek Hukum Perlindungan Anak Dalam Perspektif Konvensi Hak Anak, Bandung: Citra Aditya Bakti

[7] Krinawati, Emiliana. (2005). Aspek Hukum Perlindungan anak. Bandung

[8] Muladi. (1992). Bunga Rampai Hukum Pidana. Bandung: Alumni Publisher. p. 113

[9] Retnowulan. (1996). Hukum Acara Peradilan Anak. National Seminar on Child Protection, Faculty of Law UNPAD. Bandung

[10] Shalaby, Ahmad. (2001). Kehidupan Sosial dalam Pemikiran Islam. Jakarta: Amzah

[11] Waddong, Maulana Hassan. (2000). Pengantar Advokasi Dan Hukum Perlindungan Anak. Jakarta: PT Gramedia Indonesia

Regulations:

[1] Government Regulation Number 37 of 2007 concerning the implementation of Act No. 23 of 2006 concerning Population Administration, article 55 paragraph (2) letter a 
[2] Act No. 1 of 1974 Concerning Marriage, In the Book of the Compilation of Regulations on Religious Courts

[3] Government Regulation Number 9 of 1975 Concerning Implementation of Act No. 1 of 1974 Concerning Marriage in the Book of the Compilation of Regulations on Religious Courts 2010 